\title{
An Antimicrobial Evaluation Of Tuttha Bhasma
}

\author{
${ }^{1}$ Vaishagh P, ${ }^{2}$ Nayak Dinesh $\mathbf{J},{ }^{3}$ Shobha K L \\ ${ }^{1}$ P G student, P G department of Rasashastra and Bhaishajya Kalpana, Muniyal Institute of Ayurveda \\ Medical Sciences, Manipal. \\ ${ }^{2}$ Professor, P G department of Rasashastra and Bhaishajya Kalpana, Muniyal Institute of Ayurveda Medical \\ Sciences, Manipal. \\ ${ }^{3}$ Professor, Department of Microbiology, Melaka Manipal, Medical College, Manipal University
}

Corresponding author- Dr Vaishagh P, Muniyal Institute of Ayurveda Medical Sciences, Manipal, 576104.

\begin{abstract}
:
Tuttha Bhasma is a herbo-mineral preparation explained in Rasatarangini. The procedure includes shodhana of tuttha, gandhaka, tankana, which are mixed homogenously and triturated with Lakoocha swarasa and subjected to Kukkuta puta. This article explains about the antimicrobial activity of Tuttha Bhasma. 3 samples of tuttha bhasma was prepared and evaluated for its antimicrobial property in 4 strains. Antimicrobial study shows that, Tuttha Bhasma is having better antifungal properties than anti-bacterial properties.
\end{abstract}

Key words: Tuttha Bhasma; Tuttha; Anti-Microbial; Anti-Fungal.

\section{Introduction:}

Tuttha-copper Sulphate $\left[\mathrm{CuSO}_{4} 7 \mathrm{H}_{2} \mathrm{O}\right]$ is the artificially prepared and presently available form of Sasyaka (copper Sulphate). Tuttha is also considered as the upadhatu of Tamra and have the properties of Tamra and Sasyaka both ${ }^{1}$. The Tuttha is also called by Tutathaka, Sikhigreeva, Hemarasa and Mayoorakam in Ayurveda. Tuttha is a chemical compound obtained though processing the Sulphuric acid over the copper. Tuttha reflects the color similar to the neck of a peacock and is heavy in weight. The Tuttha has an unpleasing taste of alkali and is bitter. This is capable to penetrate into the body and to remove ringworms. It is easy to digest and very effective in curing eye diseases, scabies and ailments generated by worms and poison ${ }^{2}$.

Tuttha Bhasma is a herbo-mineral preparation explained in Rasatarangaini ${ }^{3}$. The procedure includes shodhana of tuttha, gandhaka, tankana, which are mixed homogenously and triturated with Lakoocha swarasa and subjected to Kukkuta Puta for 2 times. Tuttha Bhasma is chiefly indicated in Kushta, Svitra, Amlapitta, and Krimi ${ }^{4}$.

Antimicrobial activities of any therapeutic agent are understood by its degree of growth inhibition of microorganisms as well as bacterial property.

Usually different microbial species and strains have different degrees of susceptibility to therapeutic agents. The susceptibility of microorganisms can change with time even during therapy with a specific drug. Thus, it is essential for the physician to know the sensitivity of the pathogen before treatment.

Our ancient Indian scholars were aware of the existence of microorganisms or bacteria as well as causation of disease since Vedic period.

There are many references pertaining to Jivanuvada (bacteriology) in ancient literature such as Rigveda, Atharvaveda and Mahabharata etc which indicates familiarity of the subject in those days. 


\section{Materials and method:}

Pharmaceutical study:

The ingredients are shuddha tuttha, shuddha gandhaka, shuddha tankana and Lakucha swarasa (Atrocarpus lakoocha). The powders of above said ingredients were mixed homogenously and triturated with Lakucha swarasa. It was subjected to Kukkuta Puta ( a defined quantum of heat provided by cow-dung cakes). 3 samples of tuttha bhasma was prepared. Sample 1 was prepared by 3 kukkuta puta and sample 2 and 3 were prepared by 2 kukkuta puta.

\section{Analytical study:}

3 samples of tuttha bhasma was analysed as per classical parameters of bhasma pariksha and also using modern analytical parameters like organoleptic characteristics, physico chemical analysis, qualitative and quantitative analysis with the relevant instrumental methods like X-ray diffraction, laser diffraction method, SEM-EDAX.

\section{Antimicrobial study:}

Sample- Tuttha Bhasma 3 samples

\section{Bacterial strains used}

- Gram negative strain - Escherichia coli and Pseudomonas aeruginosa

- Gram positive strain - Staphylococcus aureus

a. Methicillin sensitive( MSSA)

b. Methicillin resistant(MRSA)

- Fungus strain - Candida albicans

Media used - Muller Hinton agar

Sabouraud's dextrose agar

Standard drug disc - Imipenem 10 microgram per disc

Ketaconazole 15 microgram per disc

\section{Preparation of inoculum}

For preparation of inoculum, identified clinical strain of all bacteria and fungi was inoculated in peptone water (Identification of the organism was done using standard procedure). It was kept undisturbed for 4 to 5 hours to multiplication. The obtained inoculum was compared with $0.5 \mathrm{McFarland}$ standard optical density of $530 \mathrm{~nm}$ corresponding to $5 \times 10^{6} \mathrm{CFU} / \mathrm{ml}$. The sterile swab containing organisms was squeezed to remove excess broth and swabbed on the culture plate with lawn culture.

\section{Preparation of drug dilution}

Each drug was suspended in distilled water at a concentration of $1 \mathrm{mg} / \mathrm{ml}$

\section{Agar well preparation for the drug}

Sterile petri dish was taken and Mueller Hinton agar was poured and left for solidification. Each plate was labelled. Standard cultures containing organisms were uniformly smeared all around the surface of the agar medium with sterile cotton swabs containing $10^{5} \mathrm{CFU} / \mathrm{ml}$ of the bacterial suspension. Wells of $6 \mathrm{~mm}$ diameter were dug in the culture medium in the petri plates. 100 microlitres of drug suspension was loaded into each well. These petri plates were incubation at $37^{\circ} \mathrm{c}$ for $18-24$ hours for bacterial growth. Sensitivity of the drug was measured by measuring the zone of inhibition .The same procedure was followed for fungus, Candida albicans using Sabouraud's dextrose agar as culture medium and incubating at $37^{\circ} \mathrm{c}$ for 48 hours and looked for zone of inhibition. 
${ }^{1}$ Vaishagh P, International Journal of Ayurvedic \& Herbal Medicine 8(4) July.-August. 2018 (3278-3284)

\section{$\underline{\text { Results and discussion: }}$}

Table no: 1 showing antimicrobial activity of Tuttha Bhasma

\begin{tabular}{|c|c|c|c|c|c|}
\hline \multirow{3}{*}{\multicolumn{2}{|c|}{ Name of organism }} & \multicolumn{4}{|c|}{ Zone diameter } \\
\hline & & \multicolumn{3}{|c|}{ Test drug } & \multirow[t]{2}{*}{ Standard drug } \\
\hline & & Sample 1 & Sample 2 & Sample 3 & \\
\hline \multicolumn{2}{|l|}{ Escherichia coli } & $15 \mathrm{~mm}$ & $15 \mathrm{~mm}$ & $17 \mathrm{~mm}$ & $25 \mathrm{~mm}$ \\
\hline \multicolumn{2}{|c|}{ Pseudomonas aeruginosa } & $17 \mathrm{~mm}$ & $19 \mathrm{~mm}$ & $21 \mathrm{~mm}$ & $25 \mathrm{~mm}$ \\
\hline \multirow{2}{*}{$\begin{array}{l}\text { Staphylococcus } \\
\text { aureus }\end{array}$} & MRSA & $25 \mathrm{~mm}$ & $25 \mathrm{~mm}$ & $24 \mathrm{~mm}$ & \multirow[t]{2}{*}{$25 \mathrm{~mm}$} \\
\hline & MSSA & $24 \mathrm{~mm}$ & $26 \mathrm{~mm}$ & $28 \mathrm{~mm}$ & \\
\hline \multicolumn{2}{|c|}{ Candida albicans } & $30 \mathrm{~mm}$ & $35 \mathrm{~mm}$ & $40 \mathrm{~mm}$ & $25 \mathrm{~mm}$ \\
\hline
\end{tabular}

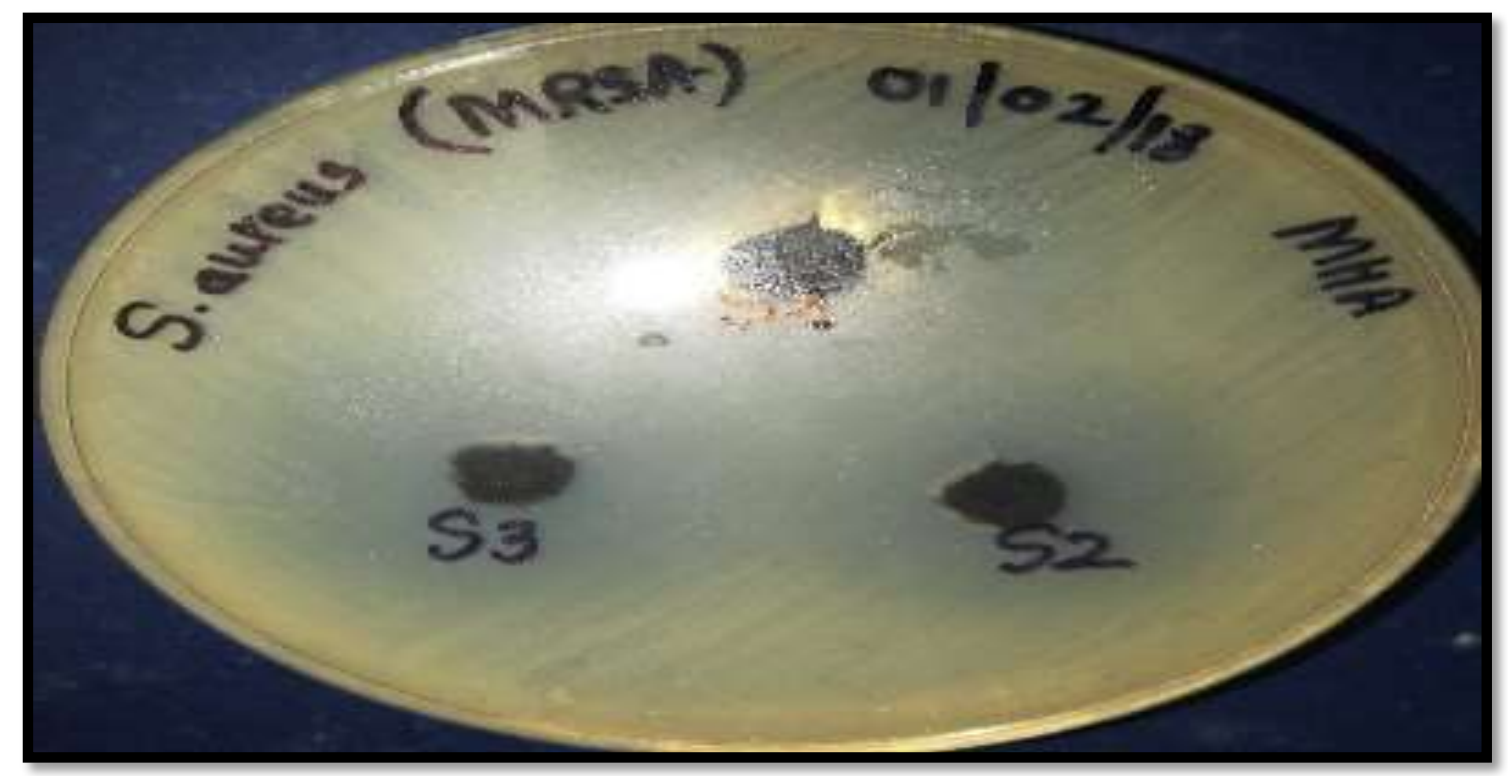

Figure no:1 antimicrobial activity in E.coli strain

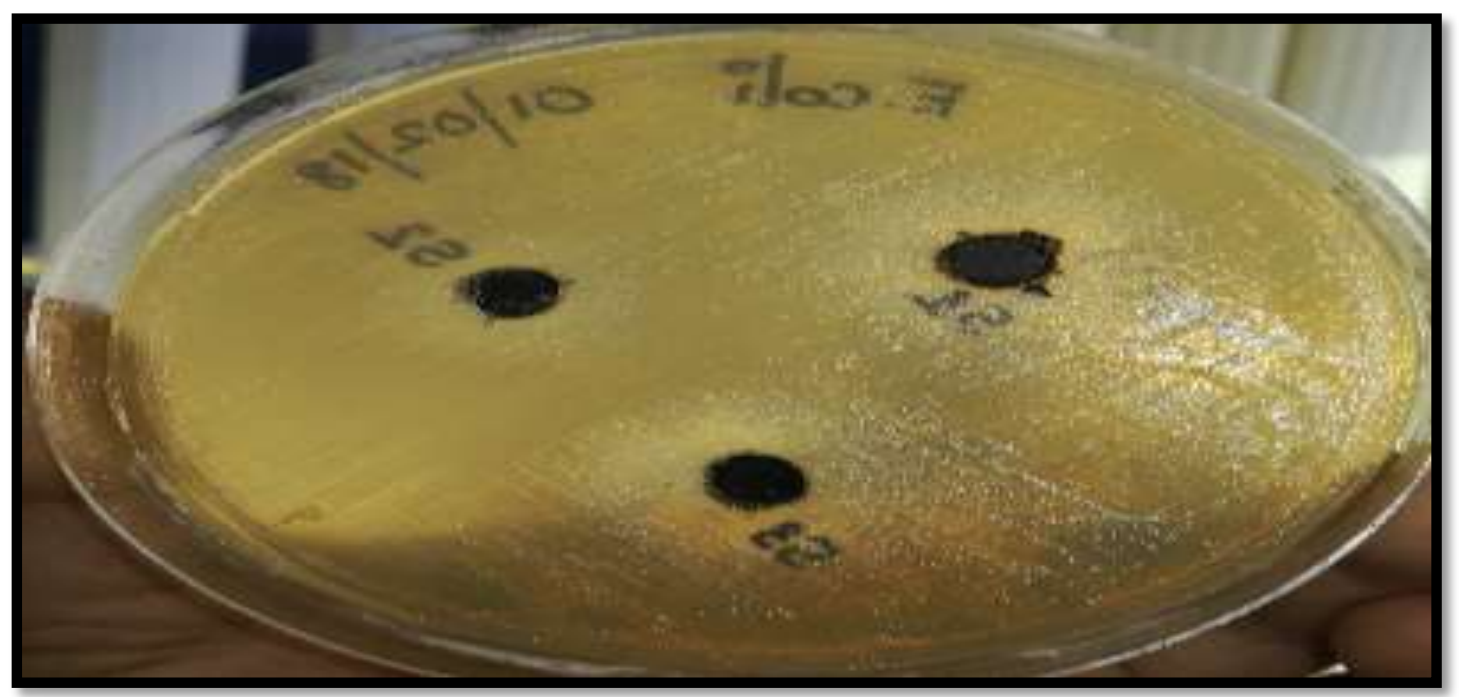

Figure no: 2 showing antimicrobial activity in pseudomonas aeroginosa 
${ }^{1}$ Vaishagh P, International Journal of Ayurvedic \& Herbal Medicine 8(4) July.-August. 2018 (3278-3284)

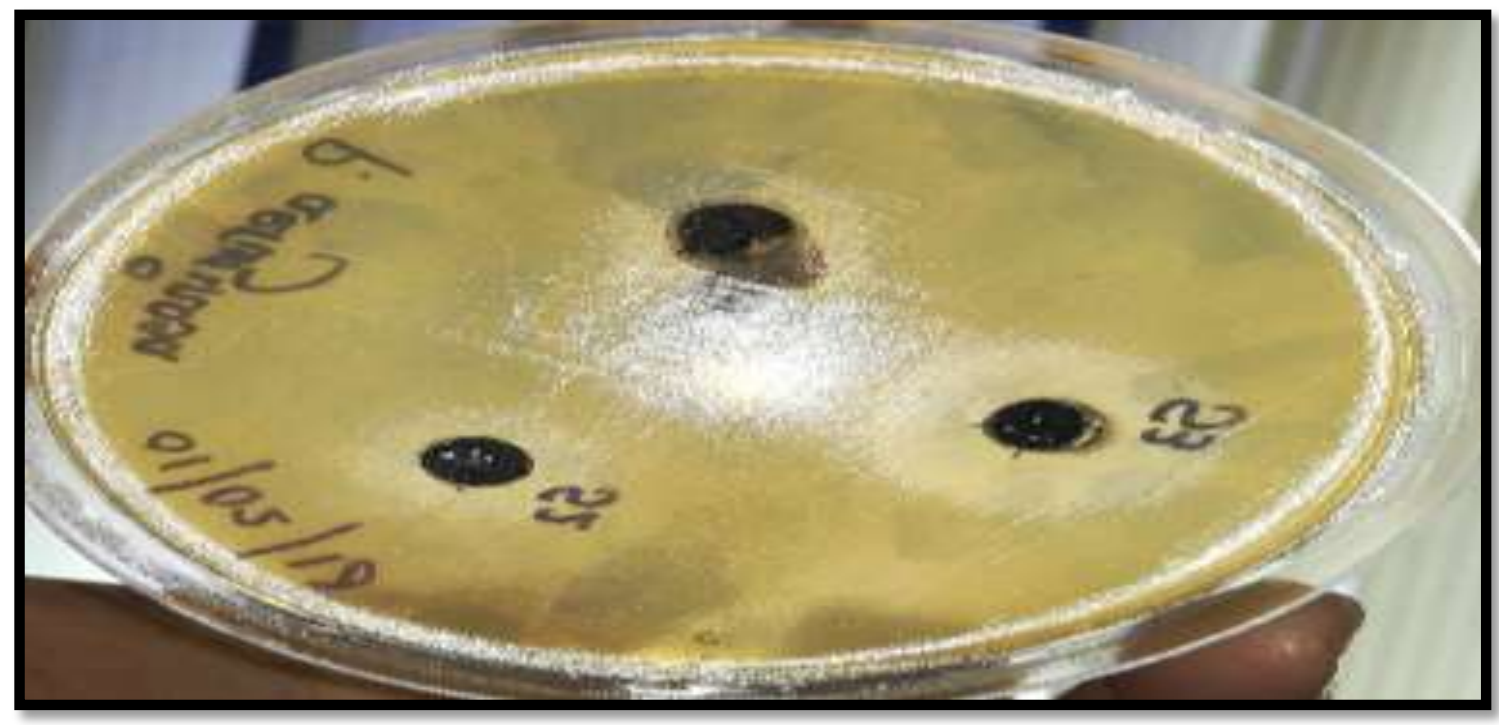

Figure no: 3 showing antimicrobial activity in staphylococcus aureus(MRSA)

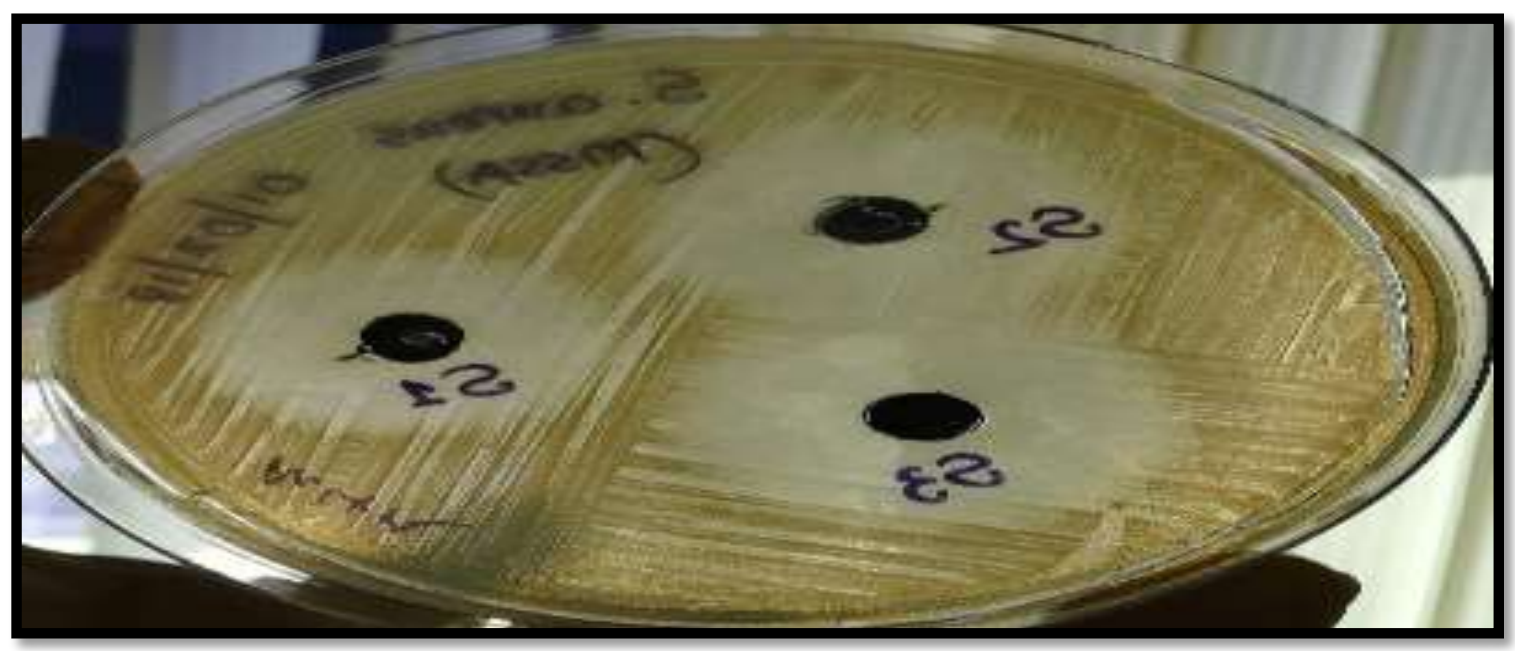

Figure no: 4 showing antimicrobial activity in staphylococcus aureus(MSSA)

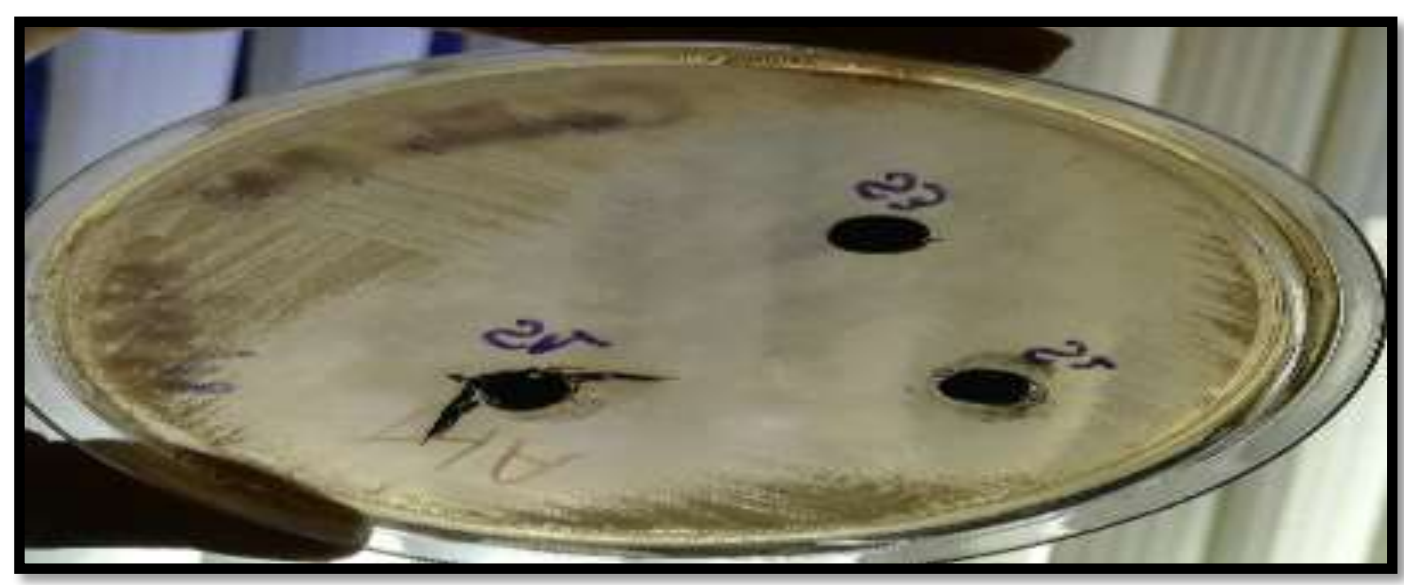

Figure no: 5 showing antimicrobial activity in Candida albicans

The antimicrobial activities of any therapeutic agents are understood by the degree of growth inhibition of microorganisms it produces as well as its bacterial side of property using different microbial species or even 
strains have different degree of susceptibility to therapeutic agents. The susceptibility of microorganisms can change with time, even during therapy to a specific drug ${ }^{5}$. Thus it is essential to the physician to know the efficacy of drug before treatment. Krimighna property of Tuttha bhasma evaluated by antibacterial, antifungal effect.

Bacterial strains used includes Gram negative staphylococcus aerues, E.coli, Pseudomonas aeruginosa and gram positive strains staphylococcus aerues and also methicillin sensitive and resistant strain and Candida albicans as fungal strain. All the samples shown mild anti-bacterial activity against E.coli where the zone of inhibition were 15 and $17 \mathrm{~mm}$ compared to $25 \mathrm{~mm}$ of standard drug. Moderate activity was shown against pseudomonas aeruginosa (zone of inhibition up to $21 \mathrm{~mm}$ ).

Good antibacterial activity was observed against staphylococcus aerues (both methicillin sensitive and resistant). Excellent antifungal activity was observed in Tuttha bhasma samples where the maximum zone of inhibition up to $40 \mathrm{~mm}$ was observed which was better than all standard drug. Hence the sample of Tuttha bhasma found to be effective in having antibacterial and antifungal property.

Comparatively Tuttha Bhasma found to be more effective in fungus rather than bacteria. CuS was found to be present in Tuttha Bhasma and Tamra Bhasma. Previous study has established that Tamra Bhasma has good in-vitro antibacterial activity ${ }^{6}$.

A study has shown that tuttha has moderate antimicrobial activity. According to this study, antimicrobial efficacy increased after Shodhana ${ }^{7}$. Present study has confirmed that Tuttha Bhasma is even more potent as antibacterial and antifungal agents when compared with Shodhita Tuttha. More potent antimicrobial activity was observed even at a lesser dosage than that of Shodhita tuttha.

\section{Conclusion:}

Comparatively Tuttha Bhasma are found to be more effective in fungus rather than bacteria

\section{References:-}

1. Madhava, Ayurveda Prakasa Edited By Shri Gulrajsharma Mishra, Published By Chaukhambha Bharati Academy,1999, Chapter No 4,P-417

2. Govind Das, Bhaishajya ratnaavali Vidhyotini Hindi Teeka by Ambikadatta Shatri; Published By Chaukhambha Prakashan: Varanasi; 20th Edition: 2010; P-19.

3. Sadananda Sharma; Rasatarangini Edited By Pandit Kashinath Shastri; Motilal Banarasidas Publication: New Delhi; 11th Edition; Reprint-2012; P-542

4. Sadananda Sharma; Rasatarangini Edited By Pandit Kashinath Shastri; Motilal Banarasidas Publication: New Delhi; 11th Edition; Reprint-2012; P-543

5. Muhammed Tariqul Islam Shajb, Dilruba Yasmin, J Horna Manjharul, Ahsan Choudary, Lalita Bhattacharjee, Sindhibjerg Formsguard, Siteilch Nazral Islam, Nutrient Composition Of Atrocarpus Lakoocha Fruit; A Minor Indigenous Fruit Can Meet The Nutrient Requirement Of Rural People Of Bangladesh.

6. Nishakumari P M, Dinesh Nayak J, Satyanarayana B, Comparative Anti-Microbial Study Of Shuddha Kasisa And Kasisa Bhasma, International Ayurvedic Medical Journal, Volume VI, Issue 4, March 2016, Page No-579 - 583.

7. Prassannakumar T, Vijaykumar G S, Swetha Singh, In Vitro Anti-Bacterial Activity of Tamra Bhasma, International Journal Of Ayurvedic Medicine, 2010, 1 [1], Page No-23 - 30. 